\title{
Towards emancipatory research methodologies with children in the African context: Practical possibilities and overcoming challenges
}

\begin{tabular}{|c|c|}
\hline \multicolumn{2}{|c|}{$\begin{array}{l}\text { Authors: } \\
\text { Kholofelo C. Motha }{ }^{1} \text { (D) } \\
\text { Matthews M. Makgamatha }{ }^{1} \text { (D) } \\
\text { Sharlene Swartz }{ }^{2} \text { (D) }\end{array}$} \\
\hline \multicolumn{2}{|c|}{$\begin{array}{l}\text { Affiliations: } \\
{ }^{1} \text { Education and Skills } \\
\text { Development Research } \\
\text { Programme, Human Sciences } \\
\text { Research Council, Pretoria, } \\
\text { South Africa }\end{array}$} \\
\hline \multicolumn{2}{|c|}{$\begin{array}{l}{ }^{2} \text { Department of Philosophy, } \\
\text { University of Fort Hare, Alice, } \\
\text { South Africa }\end{array}$} \\
\hline \multicolumn{2}{|c|}{$\begin{array}{l}\text { Corresponding author: } \\
\text { Kholofelo Motha, } \\
\text { cnunes@hsrc.ac.za }\end{array}$} \\
\hline \multicolumn{2}{|c|}{$\begin{array}{l}\text { Dates: } \\
\text { Received: } 10 \text { Apr. } 2019 \\
\text { Accepted: } 14 \text { Aug. } 2019 \\
\text { Published: } 20 \text { Nov. } 2019\end{array}$} \\
\hline \multicolumn{2}{|c|}{$\begin{array}{l}\text { How to cite this article: } \\
\text { Motha, K.C., Makgamatha, } \\
\text { M.M. \& Swartz, S., 2019, } \\
\text { 'Towards emancipatory } \\
\text { research methodologies with } \\
\text { children in the African } \\
\text { context: Practical possibilities } \\
\text { and overcoming challenges', } \\
\text { HTS Teologiese Studies/ } \\
\text { Theological Studies } 75(1) \text {, } \\
\text { a5496. https://doi.org/ } \\
\text { 10.4102/hts.v75i1.5496 }\end{array}$} \\
\hline \multicolumn{2}{|c|}{$\begin{array}{l}\text { Copyright: } \\
\text { (C) 2019. The Authors. } \\
\text { Licensee: AOSIS. This } \\
\text { is licensed under the } \\
\text { Creative Commons } \\
\text { Attribution License. }\end{array}$} \\
\hline \multicolumn{2}{|l|}{ Read online: } \\
\hline 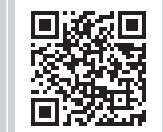 & $\begin{array}{l}\text { Scan this QR } \\
\text { code with your } \\
\text { smart phone or } \\
\text { mobile device } \\
\text { to read online. }\end{array}$ \\
\hline
\end{tabular}

Despite having international and national legislative frameworks and policies that guarantee children's rights and encourage their participation in matters affecting them, consulting children has received scant scholarly attention in the African context. Notwithstanding this state of affairs, it is important to ask whether, in keeping with growing progressive practices, having children as active researchers is a feasible goal to achieve and, if so, how might this be possible. Drawing on Swartz and Nyamnjoh's framework of research existing along an emancipatory continuum, we argue for practical, methodological interventions to bridge the researcher-researched divide. We show, using four case studies, how giving children a voice - a key feature of emancipatory research - as participants in educational research has the potential to afford them space to co-enact the research and develop their sense of agency. The four case studies were drawn from investigations of (1) lived experiences of orphaned children and conceptions of education quality in South Africa; (2) consulting children about sex and HIV / AIDS education in South Africa, Tanzania and Kenya; (3) a study of a community-based peer education programme in South Africa and (4) language and mathematics skills assessments in a large-scale study. Within each case, we (1) evaluate the extent to which the research methods used aims for and achieves children's participation and emancipation and (2) offer ways to overcome challenges for adopting emancipatory approaches in the schooling sector from ethical, policy and political perspectives. The article concludes with recommendations for implementing emancipatory methodologies in educational research involving children.

Keywords: Emancipatory methods; Children; Rights-based approach; African context; Schooling sector.

\section{Introduction}

The thrust to have children's views sought and accorded importance in matters affecting their lives is mainly informed by Article 12 of the United Nations Convention on the Rights of the Child (UNCRC) (United Nations [UN] 1990).

This right was further reinforced by Articles 1, 4 and 7 of the African Charter on the Rights and Welfare of the Child (ACRWC), which urges member states to recognise the rights and freedoms of the African child and adopt these legislative measures in accordance with their constitutions (Organisation of African Unity [OAU] 1990). The ACRWC and UNCRC place an obligation on member states to accord every child who is capable of communicating his or her views, the right and freedom to do so and enjoins that the views of the child be given due consideration in matters affecting them. In addition, Article 1 of the Charter emphasises that any custom, tradition or religious practice be consistent with these rights (OAU 1990). In this regard, the Charter, for example, suggests that religious practices should reflect the child's right to have their voices heard and their views taken seriously on matters of faith. In such contexts, child liberation theology appears to resonate with a rights-based approach. Child liberation theology is geared towards empowering all children to claim their voice, destiny and right to speak about matters of faith from their own unique perspective. Bunge (2006) argues that interpreting the bible through the lens of a child allows for a reconsideration of the central beliefs and practices of a religious tradition and exposes some of the distorted perspectives about children and childhood.

Recognising this right, and acknowledging that children have valuable knowledge and are better positioned to share knowledge on all matters affecting their lives, some researchers in the African

Note: Doing Theology with Children: Exploring Emancipatory Methodologies, sub-edited by Stephan de Beer (UP Centre for Contextual Ministry) and Hannelie Yates (North-West University). 
continent have sought innovative ways to elicit children's views on research topics affecting their lives and have engaged children as active participants and co-researchers. For example, Robson et al. (2009) involved Malawian children as co-researchers to gather data from other children on their views and experiences regarding transport and mobility. In the same way, Porter and Abane (2008) reported on a pilot study in Ghana involving children and young people aged 11-19 years as co-researchers, who through a series of capacity-building sessions were assisted to plan and carry out research. The young researchers collected data from other children using a variety of methods, analysed the data and presented their findings to a policy-maker and local stakeholders.

Several studies carried out in South Africa involved children as active participants or co-researchers (Bray \& Gooskens 2005; Ebrahim 2010; McLaughlin et al. 2012; Van der Riet, Hough \& Killian 2005; Swartz et al. 2009). For instance, Ebrahim (2010) explored constructions of childhood by children aged between 2 and 4 years at two early childhood centres in KwaZulu-Natal. Similarly, Bray and Gooskens (2005) sought participation of teenagers as research partners in recruiting potential participants and conducting interviews with them. In the same way, Van der Riet et al. (2005) reported on a pilot project using various participatory techniques and strategies with grade 3 children in KwaZulu-Natal to provide children's perspective on barriers to learning, illness and HIV / AIDS.

While acknowledging children's participation in research as a right, the researchers recognise the inherent power imbalances that exist between children and adults because of historical and cultural factors. Porter and Abane (2008), for instance, indicate that in many Ghanaian cultures, there is a strong view that children are at the bottom rung of the family and community hierarchies, and that communities ascribe to a proverbially held idea that 'children should be seen and not heard'. Children are therefore silent on matters that affect them, as well as in research.

A number of researchers are of the view that participatory approaches have the potential to address these power imbalances within the research process, particularly where research involves disempowered and vulnerable children (Morrow 2008; Morrow \& Richards 1996; Rosenthal \& Khalil 2010; Swartz \& Nyamnjoh 2018; Van der Riet et al. 2005). In addition, Morrow and Richards (1996:98) point out that one way of flattening power relations is to use age-appropriate methods and build the research capacity of children using various communication strategies. This idea is in agreement with Article 13 of the UNCRC, which gives the child the right to receive information and share it orally, either in writing or in print, in the form of art, or through any other media of the child's choice (UN 1990). Researchers, including those in the northern hemisphere, have responded to this declaration by using a variety of techniques and methodologies to invite children to receive information and express their views as active participants and co-researchers (Bray \& Gooskens 2005; Ebrahim 2010; Fleming 2010; Lundy \& McEvoy 2011; McLaughlin et al. 2012; Morrow 2008; Morrow \& Richards 1996; Porter \& Abane 2008; Punch 2002; Robson et al. 2009; Swartz et al. 2009; Van der Riet et al. 2005).

Furthermore, Van der Riet et al. (2005) pointed out that when working in developing contexts, issues of methodology and situated ethics cannot be separated. Situated ethics refers to a set of ethical practices, which takes cognisance of specific contexts, particularly those that relate to historically and socially marginalised groups of society (Ebrahim 2010; Perez 2017; Van der Riet et al. 2005), such as the status of children in their families, schools, churches or communities. The notion of situated ethics and emancipatory methodologies are thus closely related because both are about giving power to the voiceless and the marginalised (Swartz \& Nyamnjoh 2018).

This article, therefore, aims to contribute to the further understanding of innovative ethical methodologies that have emancipatory potential. We showcase this through mainly South African case studies designed with emancipatory intent and those that could be classified as conventional but have the potential to be transformed into studies with emancipatory outcomes. These studies are evaluated using Swartz and Nyamnjoh's (2018) emancipatory continuum of research methods that focus on where power lies and whose voice is pre-eminent. We highlight the challenges that may be encountered when extending emancipation-orientated research to school settings, which are characteristically bounded spaces with hierarchically established power relations among stakeholders (Charteris \& Smardon 2019). We also suggest possible ways to overcome challenges in adopting emancipatory approaches in the schooling sector from ethical, policy and political perspectives.

\section{Framework: An emancipatory continuum of research methods}

Because the focus of this article is on research methodologies that have emancipation of the researched as the ultimate goal, we draw on Swartz and Nyamnjoh's (2018) emancipatory continuum framework, which provides an analysis of research along a continuum of interactive, participatory and emancipatory methods. This framework serves as a useful guide to conduct research that aims to empower and produce useful knowledge for those who are the subjects of research. This approach to social research represents a radical departure from traditional research approaches characterised by power and research ownership being skewed to favour the researcher. The emancipatory continuum research framework, as illustrated in Figure 1, is conceptually made up of three levels, that is, interactive methods, participatory methods and emancipatory methods ordered hierarchically, with each level representing a specific orientation towards research that centres participants' voices and minimises the researcher's power in an effort to bring about emancipation for those being researched. 


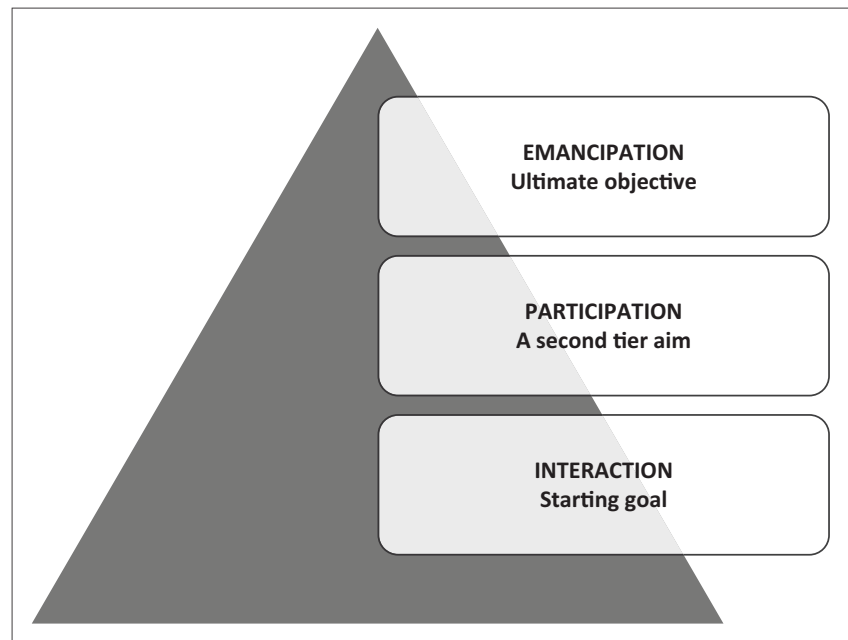

Source: Swartz, S. \& Nyamnjoh, A., 2018, 'Research as freedom: Using a continuum of interactive, participatory and emancipatory methods for addressing youth marginality', HTS Teologiese Studies/Theological Studies 74(3), 1-11. https://doi.org/10.4102/hts.v74i3.5063 FIGURE 1: Hierarchically ordered levels of research.

The power dynamics and ownership of research are ordered unidirectionally with the bottom level, with interaction, representing power and ownership, tipped in favour of the researcher. Although at this level the researcher may use interactive methods and techniques to create a space for participants' voices to be heard, the research is still researcher-owned with power resting with the researcher. The middle level of the continuum represents a shift towards equalising power and ownership of the research. The researcher and the researched become equal partners and jointly plan the research process, including dissemination of research outcomes. At the top level of the continuum, where emancipation is the goal and informs all aspects of the research, power and ownership is handed to the participants. Emancipation sees the researcher relinquishing power, thereby handing over knowledge and skills to research participants themselves, and embarking upon a practice of research, which does not perpetuate the distinction between the researcher and the researched (Oliver 2002).

In the section that follows, we present four research case studies and evaluate them using this framework to arrive at recommendations on how research among children may become increasingly emancipatory.

\section{Four research case studies and their evaluation $^{1}$}

The four research case studies were conducted mainly in South Africa, ${ }^{2}$ and involved children of school-going age. Of the four cases studies, the first two are intentionally participatory with an emancipatory goal and the other two employed traditional research approaches. With the latter, we attempt to raise awareness of the need to 'change social relations of knowledge production' (Oliver 1997:17)

1.Ethics approval for research, from which the case studies were drawn, was granted by the Research Ethics Committees of the institutions involved.

2.The study on 'Consulting children about sex and HIV/AIDS education' was conducted in South Africa, Kenya and Tanzania. to enable emancipation of the marginalised. Swartz and Nyamnjoh (2018:4) indicate that the use of interactive methods demonstrates that the traditional researcher is conscious of the importance of co-construction of knowledge and shows commitment to share power, albeit on the researcher's terms. Our evaluation of the research case studies is guided by the following questions:

- How have the research methodologies and strategies allowed for participants' voices to be heard?

- In what ways might studies be shifted along the continuum of interactive and participatory methods towards emancipatory methodologies?

\section{Consulting children about sex and HIV/AIDS education}

This study, undertaken over a 2-year period in three sub-Saharan Africa countries (Tanzania, Kenya and South Africa), explored how and what primary school-age children want to learn about sex and HIV/AIDS.

The study resulted in a book entitled Old Enough to Know (McLaughlin et al. 2012) and employed a participatory approach from the outset. It consulted widely with all the stakeholders (teachers, community leaders and parents) and employed a variety of innovative research methods with children to bring their views to the centre of the conversation about sex education - a particularly taboo subject in the African context (Mkumbo 2013). These methods included photovoice activities, mini-video documentaries, in-depth interviews, focus group interviews and dialogues. Through the photovoice activity, children learnt how to use a digital camera to document their living environments and its threats, and how to practice obtaining consent in research. They were afforded the opportunity to work together in small teams to plan, perform and video-record mini-video documentaries (comprising role-plays of how they would like to see sex education done in a classroom and how it was being done then). These visual research outputs were then discussed with children, and later with teachers, parents and community leaders. This was done to help adults see the levels of knowledge and understanding that children have about their worlds, including the threats to them of having poor or no sex education, and having it delivered in poor pedagogical style.

In this study, the researchers found that the use of participatory methods disrupted children's voices and knowledge about sex and the manner in which sex education is delivered in primary school classrooms.

Children brought into the research process their experiences and knowledge about sex from their own environments homes, communities and from the media. As young researchers, they offered alternatives to the one-way pedagogy employed in the classroom, and did so in humorous and poignant ways. Allowing them space to articulate what and how they wanted to learn about sex and AIDS education challenged cultural norms, but did so respectfully by including adults in the conversation (through dialogues) once 
children had produced their documentaries and commentaries. The knowledge produced by children had the potential to change the knowledge on sex education as part of the official curriculum.

The various interactive methods used in this case study have the potential for participatory and emancipatory outcomes beyond the research process. Through the use of photovoice and making mini-documentaries (using a mobile phone as a simple tool), primary-aged school children were engaged in co-creating a curriculum, critiquing and offering alternatives to current pedagogies. These activities allowed them to articulate knowledge that a simple verbal interview was unable to do-largely because children have been conditioned not to talk about sex to adults in the African context. They were also empowered to present this knowledge in respectful ways to adults and policy-makers (who were invited to the subsequent dialogues). These dialogues made it impossible to ignore the lived realities of children, as they spoke of what they saw going on in their communities with regard to sex (people having sex in public spaces or in full view of them), sexual dangers (being harassed by adults) and sexual temptations (being offered money for sex). Dialogues also drew on the power of the collective rather than only single voices, which is an essential component of emancipation. For children, they presented their knowledge as a collective, which allowed their voices to be heard. For adults who may have disagreed with children on a one-to-one basis, the presence of many adults resulted in a collective response that they arrived at in the process of listening to children and grappling with their own sense of cultural taboos. This resulted in adults acknowledging that while they are aware that they know this topic is taboo and hard to talk about, they need to listen even though it goes against the grain of their cultural convictions.

The use of dialogues thus created a platform for children to engage with teachers and community stakeholders on issues surrounding sexuality, which served not only to break the silence surrounding the subject but also challenged the belief that 'children should be seen and not heard'. Furthermore, community dialogues encouraged children to exercise agency, in that they developed confidence to ask questions of the adults and engage with them in a different way (McLaughlin et al. 2012). Developing children's confidence to engage with adults and allowing them voice on educational matters affecting them reflects a form of giving back to the participants with a view of achieving positive change (Swartz 2011).

In addition to this, the photovoice methodology enabled children to share their sexual knowledge from their own perspectives. Adults were even surprised at the extent and nature of knowledge that the young people had.

Lastly, dialogues with adults allowed for a better reception of children's knowledge and voices, especially on sensitive and culturally taboo matters, because it allowed adults to change cultural taboos as a collective rather than only as individuals.

\section{Peer-led HIV intervention for orphaned and vulnerable children in South Africa}

This was mainly a qualitative study aimed at assessing the impact of a peer education intervention programme on orphaned and vulnerable children aged between 10 and 13 years residing in townships and the rural context in Free State, Gauteng and KwaZulu-Natal provinces (Swartz et al. 2009). The aim of the intervention programme was to reduce and prevent high-risk behaviour such as HIV infection and teenage pregnancy among orphans and vulnerable children. The programme targeted children aged between 10 and 13 years - most of them had not yet engaged in high-risk behaviour. Peer educators, the majority aged between 14 and 17 years, facilitated the intervention programme. The research and evaluation included a quantitative element where two groups of children participated in the evaluation, that is, the intervention group and the comparison or the control group. The control group were children who were in the process of commencing with the intervention programme.

Informed by a child-friendly and rights-based perspective to research, children were given the opportunity to tell their stories and demonstrate their learning using participatory child-friendly activities, termed interactive assessment activity (IAA). The IAA consisted of nine activities, which included games, drawings and photo-elicitation. Children also participated in brief focus group and structured individual interviews.

Furthermore, the IAA was used to assess the impact of a peer education intervention programme on orphaned and vulnerable children aged between 10 and 13 years. The IAA included games, drawings, photo-elicitation, short individual interview, free lists, sentence completion and rank-ordering activities (Swartz et al. 2009). In addition, the use of innovative activities such as Me Map, drawings to relate their emotions, AIDS Avoidance Rank-Ordering Activity, Resilience Sentence Completion, People, Places and Feelings Map, 'Matchstick Balancing' and Challenge cards demonstrates a departure from conventional ways of engaging young children to talk about HIV and behaviour. The research and evaluation were tailored to the child's point of view and capabilities as research participants, acknowledging that knowledge is co-constructed.

The Me Map task used pictures to allow children to provide background information about their home environment. Creating such innovative ways to allow children to give information is consistent with the UNCRC, which gives children the right to freedom of expression to give or receive information in various forms in accordance with the age and maturity of the child (UN 1990).

Researchers took cognisance of the context of the poor and the marginalised when obtaining consent from the primary caregivers of orphaned and vulnerable children. They considered, among others, poor levels of literacy in both reading and being able to sign consent forms. 
They showed the intent to make ethical consent authentic, thus demonstrating what Van der Riet et al. (2005) and Ebrahim (2010) refer to as situated ethics, the ethical practice of being sensitive to the situation of illiterate and marginalised groups of the society.

This study reflected an emancipatory process of research as intervention in that children had acquired skills to identify support networks, the ability to make informed decisions and to assess their current situation realistically. They further displayed greater competence, confidence, understanding and self-expression than their counterparts (Swartz et al. 2009). Peer educators who were mainly children aged between 14 and 17 years reported that, as facilitators of the programme, they acquired skills that would help them find employment in the future, and build their self-esteem, confidence and communication skills. Peer educators also served as role models and were able to identify and refer children for additional support and services (Swartz et al. 2009).

\section{Lived experiences of orphaned children and conceptions of education quality}

This case is based on a doctoral study, which examined the lived experiences of orphaned primary school children residing in a township, and attending school in an informal settlement in the Gauteng province, South Africa (Motha 2010; Motha \& Frempong 2014). The children participating in the study were aged between 9 and 14 years. The aim of the study was to gain insights into how education quality could be understood from the lived experiences of orphaned children. Given that the study was researcher-led and researcher-controlled, understandings of what would constitute quality education in the life of an orphan were drawn from the data and the relevant literature. The entire research agenda was set by the researcher with no intent to empower the children. During the researcher's first contact with the participating children, she made an attempt to establish a relationship with the children by telling them about her childhood, growing up in the local township and being raised in an extended family household.

The study methods included written narratives and conversational individual interviews. The children were given an opportunity to share their lived experiences in writing. During the writing task, the researcher resolved to leave the children alone in the classroom, allow them to write freely and avoid creating a context in which children may feel that they are being monitored. Following the writing exercise, individual interviews were held to gain deeper understanding of, and to fill gaps in, the children's narratives. Both interviews and the writing tasks were one-off activities. Although the researcher visited the homes of the children, the purpose was to interview the caregivers. The researcher had no intention to build long-term relationship with the orphaned children and their families.

Lived experiences of orphaned children were adult-led with regard to the research agenda, design, authorship, and without an emancipatory intent. In terms of Swartz and Nyamnjoh's (2018) emancipatory continuum of research methods, the study is neither interactive nor participatory. At the time of the study, the researcher had no awareness of participatory approaches with its wide range of child-friendly innovative methods and techniques that would have allowed children to share experiences of their world in their own terms. Children were involved in activities such as interviews and writing their stories. However, these were solely used to collect information about orphaned children. Their 'voices' were mainly used to support the researcher's claims.

Reflecting on the use of the two methods, written narratives and interviews, the researcher assumed that children would be able to document their experiences and talk about their lived experiences. However, this was not the case as only four of the 16 children who participated in these activities were able to write and talk about their lives. The methods used served to exclude children who could have contributed valuable knowledge about perceptions of their world as orphaned learners. This, therefore, suggests that children be supported in formulating their narratives through the use of innovative child-friendly methods and techniques. Hayball and Pawlowski (2018) suggest the use of photographs in interviews. They indicate that such methods helped trigger children's memories and enabled them to express their experiences.

Furthermore, involving children as active participants would have allowed the researcher to build children's capacity to analyse data to identify indicators of education quality.

The researcher, being aware of power relations between children from impoverished home backgrounds and a $\mathrm{PhD}$ student, made an attempt to close the hierarchical gap by sharing a personal story about her childhood. This was done not only to level power relations but also to open doors for building a relationship with the participants.

Finally, 'lived experiences' has the potential to be transformed into a study that has emancipatory outcomes, particularly as the research involved vulnerable primary school children. Recognising children as co-researchers or active participants in the research process allows for interactive modes of communication beyond the conventional writing and talking methods (Gillett-Swan \& Sargeant 2018), leading to participation and ultimately emancipation of not only the orphaned child but also children in general. This would be possible if researchers change the way they view children in research and shift from asking children to describe their experiences but rather inviting them to participate as experts on children's matters (Lundy \& McEvoy 2011).

\section{Language and mathematics skills assessment}

This is a large-scale language and mathematics assessment study carried out with approximately 75000 grade 8 students in the Western Cape provincial schools in South Africa (Heugh et al. 2007). The purpose of this study was to 
benchmark student performance, diagnose their learning problems, develop and support the learning and teaching processes.

The study was decided on, funded by the Western Cape Education Department, and carried out by the Human Sciences Research Council (HSRC). Data were collected from these learners through written assessments. Furthermore, learner consent to participate in this study rested with the education authorities who provided a blanket consent for all the learners. The learners were not given the opportunity to decide whether to participate in the study or not, neither were their parents or caregivers given the right to decide on the participation of their children in the study. The power gradient in this study and similar studies is tipped in favour of the researchers and the commissioning organisation.

Nonetheless, the language and mathematics tests were designed for a multilingual and multicultural student composition in the Western Cape. Both assessments incorporated the three main languages used in the Western Cape schools, that is, Afrikaans, English and isiXhosa. This was an attempt to disrupt privileging English and Afrikaans as historically dominant languages in South Africa, to the exclusion of indigenous languages spoken by the majority of children in the province. Furthermore, this initiative served to facilitate students' equitable access to the tests, especially for those students whose home language differed from the language of the tests. The main findings revealed that the performance of students was enhanced when the home language is used as a language of assessment in mathematics.

The assessment study demonstrates how in large-scale studies power could be fully vested with the researcher and the education authorities. The children were denied the right to either agree or refuse to participate in the study. Furthermore, parental right to decide whether the child should participate in the study was also ignored.

However, the study highlights the importance of the home language in large-scale assessment studies, classroom teaching and learning and research. Language as a tool for communication, learning and thinking can serve as a powerful tool to include or exclude people in conversations or decisionmaking processes (Setati 2008). When applied to research, children could be excluded from having their voices heard in matters important to their lives because they cannot express their views in the language of the researcher, which may be English. Alternatively, children may be invited to participate in research because they have expressed an interest to participate. However, because of a lack of competence in the language of the researcher, their participation may serve as a form of tokenism. Emphasising the use of the participants' home language with the marginalised group of society, Rivera (1999:490) points out that the participants' home language 'became a fundamental tool for the production of knowledge, reflection, and social transformation'. This implies that language as a communication, learning and thinking tool can lead to empowerment of participants.

\section{Overcoming challenges to adopting emancipatory approaches in the schooling sector}

As demonstrated in two of the case studies and other empirical studies referred to in this article, it is possible to engage children as co-researchers and active participants on research matters affecting their lives.

However, working with children within the schooling sector presents its own challenges. Schooling contexts are by their very nature authoritarian, with unequal power relations operating at the various levels of the education system. These power relations are often replicated at the school level where local power is vested with school principals with subsequent power in the classroom entrusted with the teacher. In such contexts, conducting research requires researchers to obtain permission from the various adults in the hierarchy of the education system, including parents and caregivers, before they could even have contact with children to invite them to participate in the research process (Bray \& Gooskens 2005; Morrow 2008; Morrow \& Richards 1996; Sime 2008; Porter \& Abane 2008). This suggests that children's right to freedom to participate in research that may bring about change in their lives could be constrained by hierarchical and power relations inherent in the schooling system.

Adopting emancipatory approaches in such contexts would require, for example, the South African government as a signatory to the UNCRC and the ACRWC to diligently uphold its obligation by enforcing, through its constitution and the national curriculum, the right of children to have their voices heard in matters that concern them. Legislative frameworks and policies could serve as instruments to transform public schools into institutions where opportunities are created for genuine participation of children and young people to occur. Genuine participation as opposed to tokenism can begin to pave the way for children's emancipation. Robertson (2017) contends that schools have the power to either enable or constrain student agency. Considering Shier's (2001) pathways to participation and Swartz and Nyamnjoh's (2018) continuum, when institutions/schools understand children as social beings who possess a different kind of competency and abilities (Thomas \& O'Kane 1998), they could, as a starting goal, commit to entrenching a culture of participation through school policy.

Participation requires institutions to recognise the fact that children may not express their opinions to adults because there has never been a culture of participation or their opinions were previously not taken seriously or the language of communication in school is different from the home language of the child (Shier 2001).

Furthermore, we recognise the power of the collective voice and suggest that when children's voices are heard as a collective, this gives their voice much greater strength than individual voices. Within the emancipatory continuum of 
research methods, there is broad consensus that knowledge is co-constructed (Swartz \& Nyamnjoh 2018). This allows children the right to contribute knowledge on curricula, and pedagogical issues including the language of teaching, learning and assessment in schools. A move towards realisation of children's and young people's participation in their learning, teaching and assessment could include recognition and incorporation of the linguistic resources that learners bring into the learning spaces. This could include the adoption of translanguaging ${ }^{3}$ as a strategy that can facilitate equitable usage of languages for learning, teaching and assessment (Garcia \& Wei 2014; Heugh 2014; Heugh et al. 2017).

One of the barriers to engaging children as co-researchers is their lack of research knowledge and skills (Kellet 2005). This, therefore, suggests that adult researchers should begin the process of relinquishing power and control of the research process by building the capacity of children to become researchers. Considering a learning theory that is envisaged for ensuring children's participation as researchers is to understand learning through the lens of Vygotsky's sociocultural theory. Vygotsky's (1978) concept of the 'zone of proximal development' is relevant to participatory approaches in that it recognises that children are capable of operating at higher cognitive levels under the guidance of, or in collaboration with, an adult or a more capable peer (Vygotsky 1978 cited in John-Steiner \& Mahn 1996). This suggests that through innovative capacitybuilding techniques, children could be supported through collaboration with adults to set the research agenda, analyse and interpret data and engage in genuine dissemination of research findings.

Punch (2002:25) adds that the choice of the methods depends, among others, on the age, competence, preference, socioeconomic status, cultural context and the setting. For example, the use of drawings depends on children's ability to express themselves through drawing. In addition to this, adults should ensure that they do not misinterpret children's drawings. They should rather ask children to interpret their own drawings.

In Addition, Swartz and Nyamnjoh (2018) argue that it is not so much about the innovative methods and techniques used, but the intent of involving participants in the study. If the intent is to relinquish power and 'put knowledge and skills in the hands of participants themselves' (Oliver 2002:11), this would pave the way for research to belong to the participants, where it becomes not 'mine', or even 'ours' but 'theirs' (Swartz \& Nyamnjoh 2018).

As indicated in this article, methodological and ethical issues are interrelated. Recognising children as active participants or co-researchers has ethical implications. Swartz (2011) asserts that researchers would require going beyond the language in order to assist the process of making meaning in an additional language (Bock \& Mheta 2014:554). regular guidelines and standards of research ethics by employing the ethics of intentionally building trusting relationships with research participants over an extended period. In a school setting, this would require researchers to spend long periods building such relationships with the children. Another ethical practice would be flattening power relations through the use of age-appropriate methods and various communication strategies (Morrow \& Richards 1996). Furthermore, adults carry a moral responsibility to protect children by intervening when a child is identified as being at risk (Swartz 2011). Morrow and Richards (1996:98) suggest that before intervening, researchers should consider the context and the nature of the disclosure, age of the child and the relationship that the researcher had built with the child, and to discuss and agree with the child on the intervention strategy that they both would like to pursue. This is the kind of intervention that Swartz (2011) refers to as psychosocial intervention - where the researcher gives something of benefit to the participant, which can be in the form of giving advice or referring participants for help. Morrow (2008) adds the ethics of dissemination and wider reporting - pointing out that children have no power to challenge ways in which research findings about them are disseminated. However, researchers have the moral responsibility to ensure that children's views are not misrepresented.

\section{Conclusion}

We conclude that none of the four case studies were fully emancipatory in that the research agenda was set and led by the researcher. Nevertheless, as researchers employ interactive and participatory methodologies and techniques, this allows children to share knowledge and understandings from their own perspectives.

For example, the case study on 'consulting children about sex education' demonstrated how the use of participatory approaches allowed children's voices to serve as sources for reflection on the curriculum content and the manner in which sex education is taught in schools. Furthermore, children presented their knowledge on sex as a collective, which enabled their collective voice to be heard and considered by adults, which is in agreement with the principles of a rightsbased approach. Furthermore, we argue that the power of the collective, instead of single, voice is an important component of emancipation. It allows children to exercise agency. Agency provides possibilities for young people to identify their challenges, resist oppressive systems and contribute to bringing about change (Swartz et al. 2018:117).

Consequently, this form of participation draws attention to children as social agents with knowledge, experiences and ideas of their own. It further provides a fresh starting point for dialogue between adults and children on matters affecting the lives of children. In addition, participatory approaches would serve to flatten power relations between children and adults, and thus transform social institutions such as schools and churches by drawing on children's insights and expressed needs. 
Finally, notwithstanding that interactive and participatory methodologies and strategies could serve to flatten power relations between the researcher and those researched, issues of power and ownership in relation to the research process would for decades continue to rest with the researcher and the organisation funding the research. Children, as a dominated and vulnerable group of society, are voiceless with regard to decisions on what should be researched, and how data will be collected, analysed, reported on and disseminated.

Thus, relinquishing power and ownership to children, as suggested by an emancipatory approach, while an ideal, may be difficult to realise.

\section{Acknowledgements Competing interests}

The author declares that they have no financial or personal relationships which may have inappropriately influenced them in writing this article.

\section{Authors' contributions}

K.C.M. was the lead author, conducted the literature review, drafted the initial article and provided overall supervision to the writing process. M.M.M., as co-author, contributed to the theoretical framework and the discussion. S.S. conceptualised the article, provided analytical inputs to the case studies and discussion.

\section{Ethical considerations}

Three of the case studies used in the article were drawn from research approved by the HSRC Research Ethics Committee (Ethics clearance numbers: REC 9/08/02/06; REC 5/17/06/09 and REC 2/16/07/08). The fourth case study was drawn from a $\mathrm{PhD}$ research approved by the University of Pretoria Research Ethics Committee (clearance number EM08/10/01).

\section{Funding information}

The four case studies used in this paper were drawn from studies conducted in 2006, 2008 and 2009 and funded by various organisations.

'Consulting children about sex and HIV/AIDS education' was drawn from the research, 'Old Enough to Know: Consulting children about sex education in Africa', funded by The Centre for Commonwealth Education, University of Cambridge, UK.

'Peer-led HIV intervention for orphaned and vulnerable children in South Africa' was drawn from the research, "'With a little help from my friends": exploring the impact of peer-led HIV intervention and psychosocial support groups for orphaned and vulnerable children in South Africa', funded by the Harvard School of Public Health, USA.

'Language and mathematics skills assessment' was drawn from the research, 'Assessment of the Language and
Mathematics Skills of Grade 8 Learners in the Western Cape in 2006', funded by the Western Cape Education Department (Tender B/WCED 375/05).

'Lived experiences of orphaned children and conceptions of education quality' received no specific grant from any funding agency in the public, commercial or not-for-profit sectors.

\section{Data availability statement}

Data sharing is not applicable to this article as no new data were created or analysed in this study.

\section{Disclaimer}

The authors declare that they have no financial or personal relationships that may have inappropriately influenced them in writing this article.

\section{References}

Bock, Z. \& Mheta, G., 2014, Language, society and communication: An introduction, Van Schaik Publishers, Pretoria.

Bray, R. \& Gooskens, I., 2005, Ethics and the everyday: Reconsidering approaches to research involving children, Centre for Social Science Research, University of Cape Town, viewed 26 February 2019, from https://open.uct.ac.za/ handle/11427/19234

Bunge, M.J., 2006, 'The child, religion, and the academy: Developing robust theological and religious understandings of children and childhood', The Journa of Religion 86(4), 549-579, viewed 03 August 2019, from https://www.jstor.org/ stable/10.1086/505894.

Charteris, J. \& Smardon, D., 2019, 'Assessment and student participation: "Choice and voice" in school principal accounts of schooling territories', Teaching Education 30(3), 243-260. https://doi.org/10.1080/10476210.2018.1462311

Ebrahim, H.B., 2010, 'Situated ethics: Possibilities for young children as research participants in the South African context', Early Child Development and Care 180(3), 289-298, viewed 26 February 2019, from https://doi.org/10.1080/ 03004430701822958

Fleming, J., 2010, 'Young people's involvement in research: Still a long way to go?', Qualitative Social Work 10(2), 207-223, viewed 05 February 2019, from https:// doi.org/10.1177/1473325010364276

Garcia, O. \& Wei, L., 2014, Translanguaging: Language, bilingualism and education, Palgrave Macmillan, Basingstoke, viewed 19 March 2019, from https://link. springer.com/book/10.1057/9781137385765.

Gillett-Swan, J. \& Sargeant, J., 2018, 'Assuring children's human rights to freedom of opinion and expression in education', International Journal of Speech-Language Pathology 20(1), 120-127, viewed 05 February 2019, from https://doi.org/10.108 $0 / 17549507.2018 .1385852$

Hayball, F.Z.L. \& Pawlowski, C.S., 2018, 'Using participatory approaches with children to better understand their physical activity behaviour', Health Education Journa 77(5), 542-554, viewed 05 April 2019, from https://doi.org/10.1177/001789691 8759567

Heugh, H., Diedericks, G.A.M., Prinsloo, C.H. \& Herbst, D.L., 2007, Assessment of the language and mathematics skills of Grade 8 learners in the Western Cape in 2006 Human Sciences Research Council, Pretoria.

Heugh, K., 2014, 'Language contact and languaging', in Z. Bock \& G. Mheta (eds.), Language, society and communication: An introduction, pp. 361-392, Van Schaik Publishers, Pretoria.

Heugh, K., Prinsloo, C., Makgamatha, M., Diedericks, G. \& Winnaar, L., 2017, 'Multilingualism(s) and system-wide assessment: A southern perspective', Language and Education 31(3), 197-216, viewed 20 March 2019, from https://doi. org/10.1080/09500782.2016.1261894

John-Steiner, V. \& Mahn, H., 1996, 'Sociocultural approaches to learning and development: A Vygotskian framework', Educational Psychologist 33(3/4), 191-206, viewed 06 April 2019, from https://doi.org/10.1080/00461520.1996.9653266

Kellet, M., 2005, Children as active researchers: A new research paradigm for the $21^{\text {st }}$ century?, ESRC National Centre for Research Methods, United Kingdom, viewed 10 January 2019, from https://oro.open.ac.uk/id/eprint/7539.

Lundy, L. \& McEnvoy, L., 2011, 'Children's rights and research processes: Assisting children to (in)formed views', Childhood 19(1), 129-144, viewed 05 February 2019, from https://doi.org/10.1177/0907568211409078

McLaughlin, C., Swartz, S., Kiragu, S., Walli, S. \& Mohammed, M., 2012, Old enough to know: Consulting children about sex education in Africa, HSRC Press, Cape Town. 
Mkumbo, K.A.K., 2013, 'Old enough to know: Consulting children about sex and AIDS education in Africa', Sex Education: Sexuality, Society and Learning 13(4), 478-480, education in Africa', Sex Education: Sexuality, Society and Learning 13(4), 478-480,
viewed 06 February 2019, from https://doi.org/10.1080/14681811.2012.761897

Morrow, V. \& Richards, M., 1996, 'The ethics of social research with children: An overview', Children \& Society 10(2), 90-105, viewed 16 March 2019, from https:// doi.org/10.1111/j.1099-0860.1996.tb00461.x

Morrow, V., 2008, 'Ethical dilemmas in research with children and young people about their social environments', Children's Geographies 6(10), 49-61, viewed 16 March 2019, from https://doi.org/10.1080/14733280701791918

Motha, K.C., 2010, 'The relationship between education quality policies and lived experiences of orphaned learners', PhD thesis, Department of Education Management and Policy Studies, University of Pretoria, viewed 13 September 2019, from https://repository.up.ac.za/bitstream/handle/2263/28188/Complete.pdf.

Motha, K.C. \& Frempong, G., 2014, 'The lived experiences of orphaned learners in South Africa: Implications for the provision of quality education', Internationa Journal of Inclusive Education 18(7), 686-697, viewed 24 January 2019, from https://doi.org/10.1080/13603116.2013.817616

Organisation of African Unity (OAU), 1990, African Charter on the Rights and Welfare of the Child. Cab/Leg/24.9/49 (1990), Entered into Force 29 November 1999, viewed 06 February 2019, from https://au.int/sites/default/files/documents/ 30913-doc-acrwc-en.pdf.

Oliver, M., 1997, 'Emancipatory research: Realistic goal or impossible dream?', in C. Barnes \& G. Mercer (eds.), Doing disability research, pp. 15-31, The Disability Press, Leeds, UK.

Oliver, M., 2002, 'Emancipatory research: A vehicle for social transformation or policy development', Using emancipatory methodologies in disability research 1st Annual disability research seminar, Great Southern Hotel, Dublin Airport, 03 December 2002, pp. 1-18, viewed 26 March 2019, from https://www.um.es/ discatif/PROYECTO_DISCATIF/Textos.../00_Oliver3.pdf.

Perez, T.S., 2017, 'In support of situated ethics: Ways of building trust with stigmatised "waste pickers" in Cape Town', Qualitative Research 19(2), 148-163, viewed 20 March 2019, from https://doi.org/10.1177/1468794117746553

Porter, J. \& Abane, A., 2008, 'Increasing children's participation in African transport planning: Reflections on methodological issues in a child-centred research
project', Children's Geographies 6(2), 151-167, viewed 26 February 2019, from project', Children's Geographies 6(2), 151-167,
https://doi.org/10.1080/14733280801963086

Punch, S., 2002, 'Research with children: The same or different from research with adults?', Childhood 9(3), 321-341, viewed 05 February 2019, from https://doi. org/10.1177/0907568202009003005

Rivera, K.M., 1999, 'Popular research and social transformation: A community-based approach to critical pedagogy', TESL Quarterly 33(3), 485-500, viewed 06 April 2018, from https://www.jstor.org/stable/3587675.

Robertson, J., 2017, 'Rethinking learner and teacher roles: Incorporating student voice and agency into teaching practice', Journal of Initial Teacher Inquiry 3, 41-44, viewed 02 March 2019, from http://hdl.handle.net/10092/14638.
Robson, E., Porter, G., Hampshire, K. \& Bourdillon, M., 2009, “'Doing it right?": Working with young researchers in Malawi to investigate children, transport and mobility', Children's Geographies 7(4), 467-480, viewed 26 February 2019, from https://doi.org/10.1080/14733280903234535

Rosenthal, W.A. \& Khalil, D.D., 2010, 'Exploring the challenges of implementing participatory action research in the context of HIV and poverty', Curationis 33 (2), 69-77.

Setati, M., 2008, 'Access to mathematics versus access to the language of power: The struggle in multilingual mathematics classrooms', South African of Education 28(1), 103-116, viewed 06 April 2019, from https://files.eric.ed.gov/fulltext/ EJ1150009.pdf.

Shier, H., 2001, 'Pathways to participation: Openings, opportunities and obligations', Children \& Society 15(2), 107-117, viewed 02 March 2019, from https://doi. org/10.1002/chi.617

Sime, D., 2008, 'Ethical and methodological issues in engaging young people living in poverty with participatory research methods', Children's Geographies 6(1), 63-78, viewed 05 March 2019, from https://doi.org/10.1080/1473328070 1791926

Swartz, S., 2011, “Going deep" and "giving back": Strategies for exceeding ethical expectations when researching amongst vulnerable youth', Qualitative Research $11(1), 47-68$, viewed 22 February 2019, from https://doi.org/10.1177/1468794 110385885

Swartz, S., Van der Heijden, I., Makoae, M., Richter, L., Rozani, A., Runciman, T. et al., 2009, 'With a little help from my friends': Exploring the impact of peerled HIV intervention and psychosocial support groups for orphaned and vulnerable children in South Africa, Human Sciences Research Council, Cape vulnerabr.

Swartz, S., Mahali, A., Moletsane, R., Arogundade, E., Khalema, N.E., Cooper, A. et al., 2018, Studying while black: Race, education and emancipation in South African universities, HSRC Press, Cape Town.

Swartz, S. \& Nyamnjoh, A., 2018, 'Research as freedom: Using a continuum of interactive, participatory and emancipatory methods for addressing youth marginality', HTS Teologiese Studies/Theological Studies 74(3), 1-11. https://doi. org/10.4102/hts.v74i3.5063

Thomas, N. \& O'Kane, C., 1998, 'The ethics of participatory research with children', Children \& Society 12(5), 336-348, viewed 07 March 2019, from https://doi. org/10.1111/j.1099-0860.1998.tb00090.x

United Nations, 1990, Convention on the rights of the child, 20 November 1989 Entered into Force 2 September 1990, viewed 06 February 2019, from https:// www.ohchr.org/en/professionalinterest/pages/crc.aspx.

Van der Riet, M., Hough, A. \& Killian, B., 2005, 'Mapping HIV/AIDS as a barrier to education: A reflection on the methodological and ethical challenges to child participation', Journal of Education 35(1), 75-98, viewed 26 February 2019, from https://hdl.handle.net/10520/AJA0259479X_107. 